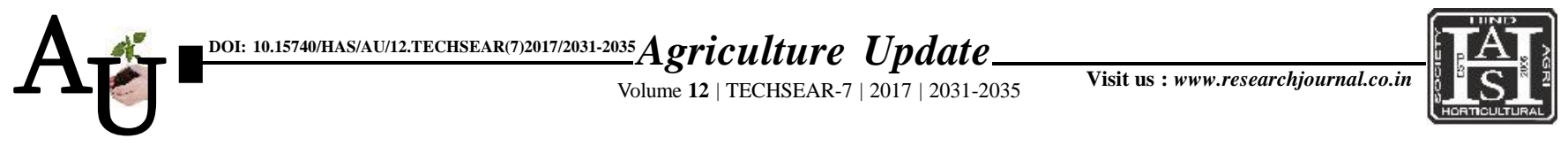

\title{
Research Article: Comparsion of micro sprinkler irrigation and surface irrigation methods on growth and yield for groundnut under Raichur region
}

\author{
MOHAMMED WASEEM, IBRAHIM KALEEL, MALLIKARJUNA AND \\ RAHUL PATIL
}

Article Chronicle :

SUMMARY : Field experiment was carried out during December 2011 to April 2012 under Raichur Received :

19.07.2017;

Accepted :

03.08.2017

climatic conditions. The performance of micro sprinkler irrigation for groundnut crop at $60 \%, 80 \%$, $100 \%$ and $120 \% \mathrm{ET}_{\mathrm{C}}$ was compared with surface irrigation. The results indicated that there was saving of $66.41 \%$ and $57.29 \%$ in 60 per cent ET and 80 per cent ET in micro sprinkler irrigation over surface irrigation. Maximum water use efficiency registered in micro sprinkler irrigation at 60 per cent ET (1.42 $\left.\mathrm{kg} \mathrm{m}^{-3}\right)$ and 80 per cent ET $\left(1.26 \mathrm{~kg} \mathrm{~m}^{-3}\right)$ with the application efficiency of $82.80 \%$ and $82.05 \%$ in 60 per cent and 80 per cent ET. Uniformity in single micro sprinkler was $89.91 \%$ and $87.69 \%$ in 100 per cent over lapping at $1.4 \mathrm{~kg} \mathrm{~cm}^{-2}$ pressure, respectively.

How to cite this article : Waseem, Mohammed, Kaleel, Ibrahim, Mallikarjuna and Patil, Rahul (2017). Comparsion

KEY WoRDS : Irrigation, Micro sprinkler, Water saving, Water efficiency, Uniformity co-efficient

Author for correspondence :

\section{IBRAHIM KALEEL}

Department of Soil and

Water Engineering,

College of Agricultural

Engineering, University

of Agricultural Sciences,

RAICHUR (KARNATAKA)

INDIA

Email :

ibrahimkhale11075@

gmail.com

See end of the article for

authors' affiliations of micro sprinkler irrigation and surface irrigation methods on growth and yield for groundnut under Raichur region. Agric. Update, 12(TECHSEAR-7) : 2031-2035; DOI: 10.15740/HAS/AU/12.TECHSEAR(7)2017/20312035. 